\title{
The Influence of Self Efficacy, Job Satisfaction and Organizational Commitment Toward Organizational Citizenship Behavior (Ocb) of Teachers Of Private Vocational Schools in South Jakarta
}

\author{
Kusumaninggati $^{1}$, Mukhneri Mukhtar ${ }^{2}$, Bedjo Sujanto ${ }^{3}$ \\ ${ }^{1}$ Doktoral Program, Human Resource Management, Jakarta State University \\ And Teacher, of Jakarta, Indonesia \\ ${ }^{2}$ Lecturer, Jakarta State University, Indonesia \\ ${ }^{3}$ Lecturer, Jakarta State University, Indonesia
}

\begin{abstract}
The objective of this research was to determine the direct influence of self efficacy, job satisfaction, organizational commitment and organizational citizenship behavior (OCB) of Vocational High Schools Teachers of South Jakarta. The research method using survey with correlation approach, in this study sampled as many as 172 teachers and selected based on a simple random technique (Simple Random Sampling). The research was done in State Vocational High School in the South of Jakarta. Based on the description in the above hypothesis test, then the research findings can be outlined as follows: (1) there is a direct and significant influence between self efficacy with organizational citizenship behavior (OCB), (2) there is direct and significant influence of job satisfaction with organizational citizenship behavior (OCB), (3) there is a direct significant influence between organizational commitment with organizational citizenship behavior (OCB), (4) there is direct and significant influence between self efficacy with organizational commitment, (5) there is direct and significant influence between job satisfaction with organizational commitment, and (6) there is direct and significant influence between self efficacy with job satisfaction.
\end{abstract}

Keywords: Self Efficacy, Job Satisfaction, Organizational Commitment, OCB.

\section{Introduction}

Voluntary behavior is the behavior of individuals who help others without direct benefits to the individuals because the beneficiary is the person who receives help. Voluntary behavior in helping others selflessly or simply want to do good is known by the term Organizational Citizenship Behavior or commonly abbreviated as OCB. Colquitt (2015) stated, "Citizenship behavior is defined as voluntary employee activities that may or may not be rewarded but that contribute to the organization by improving the overall quality of setting in which work takes place". Citizenship behavior is defined as an individual voluntary behavior that is sometimes valued or unappreciated, but it contributes to the organization in the form of quality improvement in work. This voluntary behavior may take the form of assistance to co-workers who have difficulty in completing their work. It is hoped that with such assistance, the results will be more qualified. According to Luthans (2011) Organizational Citizenship Behavior can take many forms, but the major ones could be summarized as: (1) altruism (e.g., helping out when a coworker is not feeling well); (2) conscientiousness (e.g., staying late to finish a project); (3) civic virtue (e.g., volunteering for a community program to represent the firm); (4) sportsmanship (e.g., sharing failure of a tem project that would have been successful by following the member's advice), and (5) courtesy (e.g., being understanding and empathetic even when provoked).There are several factors that influence $\mathrm{OCB}$, among them are self-efficacy, job satisfaction and organizational commitment. Self-efficacy is the belief in the ability to do a task. Research conducted by Nida Qamar (2012) states that: "As per the results and the analysis it is concluded that job satisfaction and organizational commitment have significant impact on OCB. Research conducted by Ni Made Sintya Dewi 
and I Gede Adnyana Sudibya (2016) concluded that: "Self efficacy has a direct and significant effect on Organizational Citizenship Behavior (OCB). Research conducted by Arif Budiman, Samuel PD Anantadjaya and Dea Prasetyawati (2015) concluded that: "The Influence of Job Satisfaction to OCB is 15\%". Research on the influence of organizational commitment to OCB was done by Sofiah Kadar Khan and Mohd Zabid Abdul Rashid (2012), and the results show: The results above shows that among all the variable, organizational commitment seems to be the most significantly impactful variable in explaining exhibition of OCB among employees which provided a optimisticresults in terms of selecting this as the mediating variable for organization culture, leadership style and organization justice.

\section{Objectives}

The purpose of this research is to analyze the direct influence of self efficacy, job satisfaction, and organizational commitment to organizational citizenship behavior, to analyze direct influence of self efficacy and job satisfaction to organizational commitment, to analyze direct influence of job satisfaction to organizational commitment and to analyze the direct influence of self efficacy to job satisfaction.

\section{Literature review}

\section{Organizational Citizenship Behavior (OCB).}

OCB is discretionary and helpful actions above and beyond the call of duty that promote the organization's success, (Newstrom, 2015). Organizational Citizenship Behavior (OCB) is discretionary behavior that is no part of an employee's formal job requirements, and that contributes to the psychological and social environment of the workplace, (Robbins and Judge, 2017). Organizational citizenship behaviors on behalf of the organization that go well beyond normal job expectation, and which may even serve a larger societal purpose, (Rae Andre, 2008). OCBs include behaviors such as the following: (1) Altruism (e.g., helping out when coworker is not feeling well), (2) Conscientiousness (e.g., staying late to finish project), (3) Civic Virtue (e.g., volunteering for a community program to represent the firm), (4) Sportsmanship (e.g., sharing failure of a team project that should have been successful if the team had followed your advice), (5) Courtesy (e.g., being understanding and emphatic even when provoked), (Wayne, 2013). From the concepts that have been described, it can be synthesized that OCB is employees' voluntary behavior that put forward the interests of the company and can improve the effectiveness of corporate functions, with indicators: (1) helping co-workers (altruism); (2) respecting co-workers (courtesy); (3) sportsmanship (sportsmanship); (4) obedient behavior (conscientiousness); (5) participatory behavior (civic virtue).

\section{Self-Efficacy}

Self-efficacy, also known as social cognitive theory or social learning theory refers to an individual's belief that he or she capable of performing a task (Robbins, 2017). Self-efficacy as a person's generalized belief in his or her ability to execute a course of action in any given situation (Rae Andre, 2008). Self- efficacy is the beliefs in one's capabilities to organize and execute the courses of action required to produce given attainments (Luthans, 2011). Self-Efficacy refers to an individual's convection (or confidence) about his or her abilities to mobilize the motivation, cognitive, resources, and courses of action needed to successfully execute a specific task within a given context (Luthans, 2011). In other words, people who believe they can perform well on a task (high self-efficacy) do better than those who think they will fail (low self-efficacy). Importantly for the field of organizational behavior, a stream of research studies meta-analyzed has found a strong relationship between self-efficacy and work related performance. Also, those with high self-efficacy have the tendency to remain calm in a stressful situation. In other words, there is considerable evidence that those employees with high self-efficacy tend to persevere and end up doing a good job without suffering stress or burnout (Luthans, 2011). Self-efficacy is a belief that we can perform adequately in a particular situation (Gibson, 2012). Self-efficacy have three dimensions: magnitude, the level of task difficulty a person believes she can attain; strength, referring to the conviction regarding magnitude as strong or weak; and generality, the degree to which the expectation is generalized across situations (Gibson, 2012). Selfefficacy is your belief in your capability to perform in a specific situation (Lussier, 2013). From the above concepts, it can be synthesized that self-efficacy is an individual's beliefs in his ability to do a task, overcome the situation, and take action, with indicators: (1) be able to complete the task; (2) can handle certain situations; (3) have high motivation; (4) be able to take certain actions. 


\section{Job satisfaction}

Job satisfaction as a positive feeling about a job resulting from an evaluation of its characteristics. A person with high job satisfaction holds positive feelings about the work, while a person with low satisfaction holds negative feelings (Robbins, 2017). Job satisfaction is a person's evaluation of his or her job and work context (McShane and Von Glinow, 2015). Job satisfaction is a pleasurable emotional state resulting from the appraisal of one's job or job experiences (Colquitt, 2015). Dimensions of job satisfaction: (1) The work itself-The extent to which the job provides the individual with interesting tasks, opportunities for learning, ad the chance to accept responsibility; (2) Pay-The amount of financial remuneration that is received and the degree to which this is viewed as equitable vis-à-vis that of others in the organization; (3) Promotion opportunities-The chances for advancement in the organization; (4) Supervision-The abilities of the supervisor to provide technical assistance and behavioral support; (5) Cowokers-The degree to which fellow workers are technically proficient and socially supportive (Luthans, 2011). Job satisfaction is a pleasant or unpleasant attitude felt by employees that arise as a result of work performed, with indicators: (1) Fun work, (2) Rewards are appropriate, (3) Working conditions, (4) Coworkers, and (5) Work personality suitability (Onsardi, Asmawi, Abdullah, 2017). Job satisfaction is our overall attitude toward our jobs. (Robert N. Lussier, 2013). Aspects of job satisfaction: (1) Work itself-Does the job offer responsibility, interest, challenge? (2) Quality of supervision-e task help and social support available? (3) Co-workers-How much harmony, respect, and friendliness is there? (4) Opportunities-Are there avenues for promotion, earning, and growth? (5) Pay-Is compensation, actual and perceived, fair and substantial? (6) Work conditions-Do conditions offer comfort, safety, support? (7) Security-Is the job and employment secure (Schermerhorn, 2015). The major job satisfaction facets-pay, promotion opportunities, co-workers, supervision, and the work itself-satisfaction with the work itself, far and away, best predicts overall job satisfaction (Edwin A. Locke, 2003).

Based on the opinion of the experts above it can be synthesized that job satisfaction is an emotional feeling that is pleasing to the individual to his work, with indicators: (1) feeling of pleasure towards the work itself; (2) feeling of pleasure towards the supervisor; (3) feeling of pleasure towards the co-workers; (4) feeling of pleasure towards the promotion; (5) feeling of pleasure towards the salary.

\section{Organizational Commitment}

Organizational Commitment reflects the extent to which an individual identifies with an organization and commits to its goals (Angelo Kinicki and Mel Fugate, 2016:50). Organizational commitment identifies with a particular organization and its goals and wishes to remain a member (Robbins and Timothy, 2017). Organizational Commitment is a person's emotional attachment to and identifications with their organization (Rae Andre, 2008). Organizational Commitment is the collection of feelings and beliefs that managers have about their organization as a whole (Jones and George, 2013). Organizational Commitment is the degree to which an employee identifies with the organization and is willing to put forth effort on its behalf (Noe, Hollenbeck, Gerhart, Wright, 2015). Organizational Commitment the degree to which employees believe in and accept organizational goals and want to remain with the organization (Robert $\mathrm{L}$. Mathis Jackson and Valentine, 2014). Organizational Commitment is defined as the desire on the part of an employee to remain a member of organization (Colquitt, 2015). Based on the above concepts, it can be synthesized that the organizational commitment is the desire of individuals to know a particular organization and the desire to remain as members of the organization, with indicators: (1) the recognition of an individual to a particular organization; (2) individual's loyalty to the organization; (3) the individual's desire to take part in the organization advancement; (4) the individual's emotional attachment to the organization; and (5) the individual's desire to remain a member of the organization.

Based on the literature reviewed, the following hypotheses were formulated:

H1. Self-efficacy has a direct positive effect on OCB.

H2. Job satisfaction has a direct positive effect on OCB.

H3. Organizational commitment has a direct positive effect on OCB.

H4. Self-efficacy has a direct positive effect on Organizational commitment.

H5. Job satisfaction has directly positive effect on Organizational commitment. 
H6. Self-efficacy has a direct positive effect on Job satisfaction.

\section{Conceptual framework}

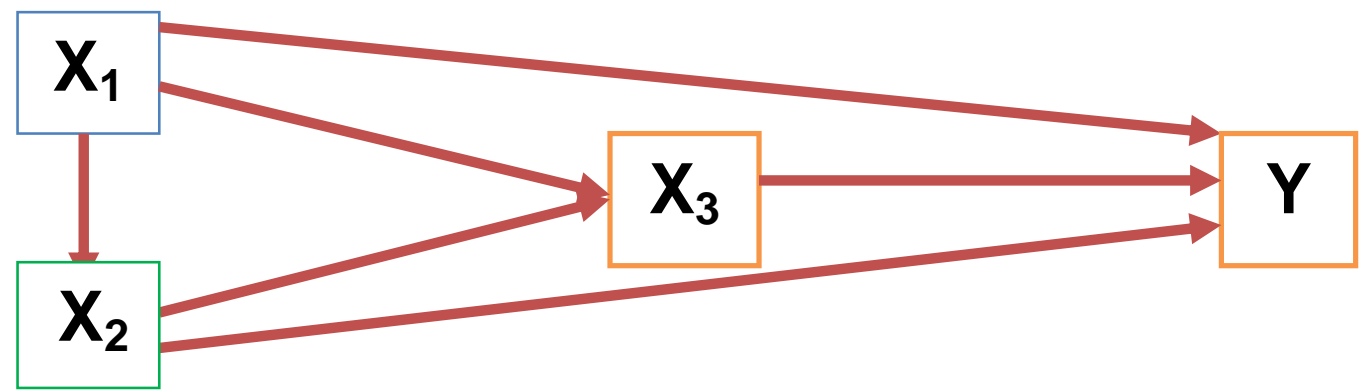

\section{Research Methodology}

This study uses the quantitative approach. The research method is the survey method with the path analysis (the path analysis technique). Covered population is all full time teachers of private vocational schools in South Jakarta, amounting to 303 teachers coming from 23 schools. Using Slovin formula, out of the total population, 172 teachers were obtained as the research samples. The technique used is the simple random technique.

\section{Result}

Sub-structure model 1

Table 1. Coefficients Sub-Structure 1

\section{Coefficients $^{\mathrm{a}}$}

\begin{tabular}{|c|c|c|c|c|c|c|}
\hline \multirow{2}{*}{\multicolumn{2}{|c|}{ Model }} & \multicolumn{2}{|c|}{$\begin{array}{c}\text { Unstandardized } \\
\text { Coefficients }\end{array}$} & $\begin{array}{c}\text { Standardized } \\
\text { Coefficients }\end{array}$ & \multirow[t]{2}{*}{$\mathrm{T}$} & \multirow[t]{2}{*}{ Sig. } \\
\hline & & B & Std. Error & Beta & & \\
\hline \multirow{4}{*}{1} & (Constant) & 31,694 & 7,635 & & 4,151 & ,000 \\
\hline & $\mathrm{X} 1$ & ,382 & ,071 & ,382 & 5,396 &, 000 \\
\hline & $\mathrm{X} 2$ & ,248 & ,073 & ,271 & 3,395 & ,001 \\
\hline & X3 & , 164 & ,066 & ,210 & 2,502 & ,013 \\
\hline
\end{tabular}

Dependent Variable: OCB (Y)

\section{H1.There is a direct positive effect of Self Efficacy $\left(X_{1}\right)$ toward Organizational Citizenship Behavior (Y) .}

Statistical hypothesis tested:

$\mathrm{H} 0=\beta \mathrm{y} 1 \leq 0$

$\mathrm{H} 1=\beta \mathrm{y} 1>0$

The result of analysis in table 1 . above by using backward method, obtained path coefficient contained in column Standardized Coeffisients (Beta) that coefficient of path py $1=0,382 ;$ t0 $=5,396$, p-value $=0,000<$ 0,05 , then $\mathrm{H} 0$ is rejected $\mathrm{H} 1$ accepted. This means that the self-efficacy variable $\left(\mathrm{X}_{1}\right)$ has a direct positive effect on OCB (Y).

H2.There is a direct positive influence of Job Satisfaction $\left(X_{2}\right)$ toward Organizational Citizenship Behavior (Y).

Statistical hypothesis tested:

$\mathrm{H} 0=\beta \mathrm{y} 2 \leq 0$

$\mathrm{H} 1=\beta \mathrm{y} 2>0$

The analysis result obtained coefficient path py $2=0,271 ; \mathrm{t} 0=3.395$, $\mathrm{p}$-value $=0,000<0.05$, then $\mathrm{H} 0$ is rejected $\mathrm{H} 1$ accepted. This means the job satisfactin variable $\left(\mathrm{X}_{2}\right)$ has a direct positive effect on OCB $(\mathrm{Y})$. 
H3.There is a direct positive influence of Organizational Commitment $\left(\mathrm{X}_{3}\right)$ toward Organizational Citizenship Behavior (Y).

Statistical hypothesis:

$\mathrm{H}_{0}: \beta \mathrm{y}_{3} \leq 0$

$\mathrm{H}_{1}: \beta \mathrm{y}_{3}>0$

Path analysis result obtained py $3=0,210 ; \mathrm{t} 0=2,502$, p-value $=0.013<0.05$, then $\mathrm{H} 0$ is rejected $\mathrm{H} 1$ accepted. This means that organizational commitment $\left(\mathrm{X}_{3}\right)$ has a direct positive effect on $\mathrm{OCB}(\mathrm{Y})$.

Sub-structure model 2

Table 2. Coefficients Sub-Structure 2

Coefficients $^{\mathrm{a}}$

\begin{tabular}{|rl|r|r|r|r|r|}
\hline \multirow{2}{*}{ Model } & \multicolumn{2}{|c|}{$\begin{array}{c}\text { Unstandardized } \\
\text { Coefficients }\end{array}$} & $\begin{array}{l}\text { Standardized } \\
\text { Coefficients }\end{array}$ & \multirow{2}{*}{ T } & \multirow{2}{*}{ Sig. } \\
\cline { 2 - 5 } & \multicolumn{1}{|c|}{ B } & Std. Error & \multicolumn{1}{c|}{ Beta } & & \\
\hline \multirow{2}{*}{ (Constant) } & $-10,192$ & 8,918 & & $-1,143$ &, 255 \\
& X1 &, 431 &, 076 &, 337 & 5,674 &, 000 \\
& X2 &, 647 &, 070 &, 552 & 9,295 &, 000 \\
\hline
\end{tabular}

a. Dependent Variable: organizational commitment (X3)

H4.There is a direct positive effect of Self Efficacy $\left(X_{1}\right)$ toward Organizational Commitment $\left(X_{3}\right)$. Statistical hypothesis:

$\mathrm{H}_{0}: \beta_{31} \leq 0$

$\mathrm{H}_{1}: \beta_{31}>0$

The results of analysis in table 2 above, using backward method, obtained path coefficient contained in the column Standardized Coeffisients (Beta), p31 $=0.337$; $\mathrm{t} 0=5,674$, $\mathrm{p}$-value $=0,000<0,05$, then $\mathrm{H} 0$ is rejected, $\mathrm{H} 1$ is accepted. This means that the self-efficacy variable (X1) has a direct positive effect on organizational commitment $\left(\mathrm{X}_{3}\right)$.

H5.There is a direct positive effect of Job Satisfaction $\left(X_{2}\right)$ toward Organizational Commitment $\left(X_{3}\right)$. Statistical hypothesis:

$\mathrm{H}_{0}: \beta_{32} \leq 0$

$\mathrm{H}_{1}: \beta_{32}>0$

Test results with path analysis obtained coefficient $\mathrm{p} 32=0,552 ; \mathrm{t} 0=9.295$, $\mathrm{p}$-value $=0.000<0,05$, then H0 is rejected, $\mathrm{H} 1$ is accepted. This means the job satisfaction variable $\left(\mathrm{X}_{2}\right)$ has a direct positive effect on organizational commitment $\left(\mathrm{X}_{3}\right)$.

Sub-structure model 3

Table 3. Coefficients Sub-Structure 3

Coefficients $^{\mathrm{a}}$

\begin{tabular}{|c|c|c|c|c|c|}
\hline \multirow[t]{2}{*}{ Model } & \multicolumn{2}{|c|}{$\begin{array}{c}\text { Unstandardized } \\
\text { Coefficients }\end{array}$} & $\begin{array}{l}\text { Standardized } \\
\text { Coefficients }\end{array}$ & \multirow[t]{2}{*}{$\mathrm{T}$} & \multirow[t]{2}{*}{ Sig. } \\
\hline & $\mathrm{B}$ & Std. Error & Beta & & \\
\hline (Constant) & 39,650 & 9,343 & & 4,244 &, 000 \\
\hline $\mathrm{X} 1$ &, 723 & ,063 & ,662 & 11,506 & ,000 \\
\hline
\end{tabular}

a. Dependent variable: job satisfaction $\left(\mathrm{X}_{2}\right)$

H6.There is a direct positive effect of Self Efficacy $\left(X_{1}\right)$ toward Job Satisfaction $\left(X_{2}\right)$.

Statistical hypothesis:

$\mathrm{H}_{0}: \beta_{21} \leq 0$

$\mathrm{H}_{1}: \beta_{21}>0$ 
Based on table 3 the above coeficients obtained p21 $=0.662$ t0 $=11,506$, p-value $=0.000<0.05$, then $\mathrm{H} 0$ rejected $\mathrm{H} 1$ accepted. This means that the self-efficacy variable $\left(\mathrm{X}_{1}\right)$ has a direct positive effect on the job satisfaction variable $\left(\mathrm{X}_{2}\right)$.

\section{Discussion}

\section{The Influence of Self-efficacy toward OCB.}

Self-efficacy has a direct positive impact on OCB. This positive direct impact indicates that high selfefficacy leads to an increase in OCB, and vice versa, low self-efficacy affects the decreasing OCB occurring within the organization. The findings of this study are relevant to the results of research conducted by Ainimazita Mansor, Amer Darus, Mohd. Hasani Dali (2013), Self efficacy has a direct effect on Organizational Citizenship Behavior (OCB). In addition, research conducted by Amal Sobhy Mahmoud and Sanaa Abd El Azim Ibrahim (2016) also found that organizational citizenship behavior is influenced by organizational justice and self-efficacy among nurses. According to the results of this research, nurse managers must enhance and maintain organizational citizenship behaviors among nurses through a system of tangible and intangible rewards.

\section{The Influence of Job Satisfaction toward OCB.}

Job Satisfaction has a direct positive impact on OCB. This positive direct impact indicates that high job satisfaction leads to an increase in OCB, and vice versa, low Job Satisfaction affects the decreasing OCB occurring within the organization. The findings of this study are relevant to the results of research conducted by Deww Zhang (2011), OCB has been shown to have a positive impact on employee performance and well being, and this in turn has noticeable flow-on effects on the organisation. However, certain types of performance-primarily those related to citizenship behaviour-will be affected by job satisfaction. In addition, research conducted by Nida Qamar (2012), As per the results and the analysis it is concluded that job satisfaction and organizational commitment have significant impact on OCB.

\section{The Influence of Organizational Commitment toward OCB.}

Organizational commitment has a direct positive impact on OCB. This positive direct impact indicates that high organizational commitment leads to an increase in $\mathrm{OCB}$, and vice versa, low organizational commitment affects the decreasing OCB occurring within the organization. The findings of this study are relevant to the results of research conducted by of Chang, Chi-Cheng, Tsai, Meng-Chen, Tsai, MengShan (2011), The results, we have three findings: (1) the organizational citizenship behaviors positively influence the effects of organizational learning; (2) the organizational commitments positively influence the effects of organizational learning, and (3) the organizational commitments positively influence organizational citizenship behaviors. In addition, research conducted by Sofiah Kadar Khan dan Mohd Zabid Abdul Rashid (2012), The results above shows that among all the variable, organizational commitment seems to be the most significantly impactful variable in explaining exhibition of OCB among employees which provided a optimistic results in terms of selecting this as the mediating variable for organization culture, leadership style and organization justice.

\section{The Influence of Self Efficacy toward Organizational Commitment}

Self-efficacy has a direct positive influence toward organizational commitment. This positive direct influence indicates that high self-efficacy leads to an increase in organizational commitment, and vice versa, low self-efficacy impacts on decreasing organizational commitment. The findings of this research are in line with research conducted by Aisyah A. R. (2012); There is a direct influence on self-efficacy and organizational commitment.

\section{The Influence of Job Satisfaction toward Organizational Commitment}

Job satisfaction has a direct positive influence toward organizational commitment. This positive direct influence indicates that high job satisfaction leads to an increase in organizational commitment, and vice versa, low job satisfaction impacts on decreasing organizational commitment. The findings of this research are in line with research conducted by Dyah Sawitri, Endang Suswati, and Khasbulloh Huda (2016), Job satisfaction also influenced Organization Commitment. In addition, research conducted by Ms. Chetna 
Pandey and Mrs. Rajni Khare (2012), The findings of the research conclude that there is a significant impact of job satisfaction and organizational commitment on employee loyalty in manufacturing industry and in case of service industry job satisfaction has an impact on employee loyalty but organizational commitment has no impact on employee loyalty.

\section{The Influence of Self-efficacy toward Job Satisfaction.}

Self-efficacy has a direct positive impact on job satisfaction. This positive direct impact indicates that high self-efficacy leads to an increase in job satisfaction, and vice versa, low self-efficacy affects the decreasing job satisfaction occurring within the organization. The findings of this study are relevant to the results of research conducted by Aikaterini Gkolia, Dimitrios Belias dan Athanasios Koustelios (2014), All the studies provide strong evidences that self-efficacy influence individuals' job satisfaction. A Literature review has shown that teachers' self-efficacy has an influence on teachers' job satisfaction. Peterlang (2010) Teachers self efficacy effect job satisfaction directly and indirectly, owing to its impact on perceptions of support emotional exhaustion and professional achievement. Bandura dan Schunk (2004), Self efficacy is one of the factors influences job satisfaction, self efficacy means confidence is one capability in implementing a certain behavior successfully and they the expected result are obtained. In addition, research conducted by Carol Lee Mc Arthur (2008): Self-efficacy beliefs have been found to be the "main determinants" of teachers job satisfaction. Further, perception of collective efficacy are influential in the development of teacher job satisfaction. Specially, these researches determined that construct are most significant at the school level of the organization.

\section{Conclusion}

The conclusion of this research shows that there is direct positive influence of self efficacy, job satisfaction, and organizational commitment to Organizational Citizenship Behavior (OCB). There is a direct positive influence of Self efficacy and job satisfaction to organizational commitment. There is a direct positive influence of self efficacy to job satisfaction.

\section{Recommendation}

The foundation should adjust teacher salaries, provide incentives to teachers, and provide facilities needed by teachers to support teaching and learning activities. The principal should ensure that all teachers are given teaching assignments in accordance with their educational background and competence, allowing teachers to develop themselves by including teachers in out-of-school training and allowing them to take positions as committees alternately in activities held within the school environment. Teachers should understand the vision and mission of the schools, willing to give ideas and willing to take concrete steps to add value to the school. Teachers should recognize their potentials and be willing to develop their potential through participation in various trainings and subject teachers meetings to become qualified teachers, so as to achieve school progress.

\section{References}

[1] Aisyah A.R. The Influence of Self-Efficacy, Emotional Intelligence, Innovativeness and Organizational Commitment on the Performance of the Echelon III Employees in Palembang. International Journal of Science and Research (IJSR) ISSN (Online): 2319-7064 Impact Factor (2012): 3.358 .

[2] Andre, Rae. Organizational Behavior: Fourth Edition. New York: Mc-Graw Hill Education, 2008.

[3] Bandura, Albert, Schunk DH. Self-efficacy. New York: Cambridge University Press, 2004.

[4] Budiman, Arif, Samuel PD Anantadjaya and Dea Prasetyawati. Does Job Satisfaction Influence Organizational Citizenship Behavior? An Empirical Study in Selected 4-Star Hotels in Jakarta, Indonesia. Business and Economics Research, Vol. 3 (1), h. 146.

[5] Cascio, Wayne F. Managing Human Resources: Productivity, Quality of Work Life, Profits. New York: McGraw-Hill, 2013.

[6] Chang, Chi-Cheng, Tsai, Meng-Chen, Tsai, Meng-Shan. The Organizational Citizenship Behaviors and Organizational Commitments of Organizational Members Influences the Effects of 
Organizational Learning. International Journal of Trade, Economics and Finance, Vol.2, No.1,February, 2011 2010-023X.

[7] Colquitt, Jason A., LePine and Wesson. Organizational Behavior Improving Performance and Commitment in the Workplace. New York: McGraw-Hill Education, 2013.

[8] Dewi, Ni Made Sintya and I Gede Adnyana Sudibya. Pengaruh Efikasi Diri terhadap Organizational Citizenship Behavior dengan Kepuasan Kerja sebagai variabel mediasi. E-Jurnal Managemen Unud, Vol. 5, no. 11, 2016:7473-7499. ISSN 2302-8912.

[9] Gibson, James L., James H. Donelly, John M. Ivancevich, and Robert Konopaske. Organizational Behavior, Structure, Process. New York: McGraw-Hill, 2012.

[10] Gkolia, Aikaterini, Dimitrios Belias and Athanasios Koustelios. Teacher's Job Satisfaction and SelfEfficacy: A Review. European Scientific Journal, August 2014 edition vol.10, No.22 ISSN: 18577881 (Print) e-ISSN 1857-7431.

[11] Jones and George. Essentials of Contemporary Management. New York: McGraw-Hill/Irwin, 2013.

[12] Khan, Sofiah Kadar and Mohd Zabid Abdul Rashid. The Mediating Effect of Organizational Commitment in the Organizational Culture, Leadership and Organizational Justice Relationship with Organizational Citizenship Behavior: A Study of Academicians in Private Higher Learning Institutions in Malaysia. International Journal of Business and Social Science, Vol. 3 No. 8, Special Issue-April 2012.

[13] Kinicki, Angelo and Mel Fugate. Organiztional Behavior: a Practical, Problem-Solving Approach. New York: McGraw-Hill Education, 2016.

[14] Locke, Edwin A. The Blackwell Handbook of Principles of Organizational Behavior. New York: The Blackwell, Publishing, 2003.

[15] Luthans, Fred, Organization Behavior: An Evidence-Based Approach. New York: McGraw-Hill, 2011.

[16] Lussier, Robert N. Human Relations in Organizations: Application and Skill Building. New York: The McGraw-Hill Education, 2013.

[17] Mahmoud, Amal Sobhy and Sanaa Abd El Azim Ibrahim. Factors in Nurses' Organizational Citizenship Behavior. IOSR Journal of Nursing and Health Science (IOSR-JNHS) e-ISSN: 23201959.p- ISSN: 2320-1940 Volume 5, Issue 2 Ver. VI (Mar. - Apr. 2016).

[18] Mansor, Ainimazita, Amer Darus, Mohd. Hasani Dali. Mediating Effect of Self-Efficacy on SelfLeadership and Teachers' Organizational Citizenship Behavior: A Conceptual Framework. International Journal of Economics Business and Management Studies-IJBMS, Vol. 2 (1), Pring 2013.

[19] Mathis, Robert L., Jackson and Valentine. Human Resources Management. USA: Cengage Learning, 2014.

[20] McShane and Von Glinow. Organizational Behavior: Emerging Knowledge, Global Reality. United States: McGraw-Hill Education, 2015.

[21] Mc Arthur, Carol Lee, Teacher Retention in Special Education: Efficacy, Job Satisfaction and Retention of Teacher in Private Schools Serving Students with Emotional Behavioral Disabilities. New Jersey: ProQuest LLC, 2008.

[22] Newstrom, John W. Organizational Behavior: Human Behavior at Work, Fourteenth Edition. New York: McGraw-Hill, 2015.

[23] Noe, Raymond A., John R. Hollenbeck, Barry Gehart and Patrick M. Wright. Human Resources Management. United Kingdom: McGraw-Hill Education, 2015.

[24] Onsardi, Moch. Asmawi M, Thamrin Abdullah. The Effect Of Compensation, Empowerment, And Job Satisfaction On Employee Loyalty. International Journal of Scientific Research and Management (IJSRM).Volume.5. Issue.12. 2017

[25] Pandey, Ms. Chetna and Mrs. Rajni Khare. Impact of Job Satisfaction and Organizational Commitment on Employee Loyalty. IRJC International Journal of Social Science \& Interdisciplinary Research, Vol.1 Issue 8, August 2012, ISSN 22773630.

[26] Peterlang, Their Hopes Fears and Reality. Germany: Library of Congress Cataloging in Publication Data, 2010. 
[27] Qamar, Nida. Job Satisfaction and Organizational Commitment as Antecedents of Organizational Citizenship Behavior (OCB). Interdisciplinary Journal Of Contemporary Research In Business, Vol. 4, No. 7 November 2012.

[28] Robbins, Stephen P. and Timothy A. Judge. Organizational Behavior . England: Pearson Education Limited, 2017.

[29] Sawitri, Dyah, Suswati, Endang, Huda, Khasbulloh. The Impact of Job Satisfaction, Organization Commitment, Organization Citizenship Behavior (OCB) on Employees' Performance. International Journal of Organizational Innovation, Vol. 9 Issue 2, 22 p. 2 Diagrams, 9 Charts. Oct. 2016.

[30] Schermerhorn, John R., Osborn, Hunt, and Uhl-bien. Organizational Behavior. New Jersey: John Wiley and Sons, 2012.

[31] Zhang Deww (4629331), "PSYCH761 White papper (OCB) 2011. www.iosrjournals.org 